\title{
Rebeldes literários:
}

\section{intelectuais e nacionalismo na Primeira República*}

Ângela de Castro Gomes**

DUTRA, Eliana Regina de Freitas. Rebeldes literários da República: história e identidade nacional no Almanaque Brasileiro Garnier (1903-1914), Belo Horizonte, Editora da Universidade Federal de Minas Gerais, 2005, 253 p.

Corria a primeira década do século XX e a segunda da República no Brasil, quando a Livraria Garnier, uma das mais tradicionais e prestigiosas casas editoras do Rio de Janeiro, decidiu publicar um almanaque que marcaria os anos nos quais circulou: o Almanaque Brasileiro Garnier (19031914). Uma opção nada banal, pois se desejava utilizar a tradição de um gênero de impresso popular, consagrado na Europa há séculos e conhecido no Brasil, para conquistar leitores, divulgando, preferencialmente, au- tores e livros editados pela Garnier. Sem dúvida, uma moderna estratégia de mercado, mas que em nada prejudicava a possibilidade de difundir idéias e valores entre um amplo público leitor que acabava de ver proclamada a República. Ao menos, é assim que pensam os editores convidados para o Almanaque, Ramiz Galvão e João Ribeiro, bem como o amplo grupo de intelectuais por eles mobilizado para contribuir na publicação. Tratava-se, e esta é a tese da autora, de fazer do Almanaque Brasileiro Garnier um

\footnotetext{
* Resenha recebida em março de 2006 e aprovada para publicação em julho de 2006.

** Professora Titular de História do Brasil na Universidade Federal Fluminense e Pesquisadora sênior do CPDOC/FGV.
} 
"vetor cultural" capaz de instruir e civilizar o povo da nova nação, ainda tão desprovida de escolas e de livros. Tratava-se de torná-lo um "substitutivo funcional do livro", uma espécie de "biblioteca portátil" e, como tal, um instrumento eficiente para a difusão de um projeto político e intelectual (então indissociáveis), voltado para a construção de um Brasil republicano e moderno.

É este impresso, fonte e objeto do livro de Eliana de Freitas Dutra, a chave utilizada para abrir as portas do mundo das letras e do mundo da política de inícios da Primeira República para seu leitor. Vivia-se, então, no Brasil, um tempo de razoável estabilidade política - garantida pelo recente pacto entre as elites oligárquicas - e de razoável progresso econômico - sustentado, basicamente, pelas exportações do café e da borracha. Um tempo que antecedeu à Primeira Guerra Mundial, que abalou internacionalmente as convicções políticas e intelectuais no progresso, na ciência, na humanidade etc. Convicções compartilhadas pelos autores do Almanaque e por muitos outros, não só no Brasil, todos eles ciosos do valor da educação e da missão iluminista dos intelectuais. Convicções de fundo nacionalista que, no caso desse grupo do Garnier, incluíam tanto uma valorização e um desejo de sustentação do regime repu- blicano enquanto forma de governo, como uma crítica ácida às práticas políticas então implementadas pelas elites no controle do poder.

Desta forma, este livro se inclui em uma vertente da historiografia que vem retomando a Primeira República como um período rico e estratégico para a história política e cultural do Brasil. Neste conjunto e engrossando os estudos sobre história do livro e da leitura, ele ressalta os esforços desenvolvidos por muitos e diferenciados intelectuais-políticos (pois eles têm as duas faces ao mesmo tempo), visando à produção de uma "pedagogia da nacionalidade". Como sua autora demonstra, ao examinar as páginas do Almanaque, tais intelectuais estabelecem estratégias políticas e retóricas complexas e delicadas para executar seu projeto, delineado por meio de um exame cuidadoso do trabalho de edição, realizado pelos organizadores do Garnier. Assim, a narrativa do livro é construída para evidenciar que "sentido de nacionalidade" estava sendo definido e defendido pelos editores do Almanaque e, por tal razão, não se estrutura segundo o trajeto cronológico da publicação. A eficiente opção metodológica encontrada buscou selecionar as temáticas fortes do periódico, por meio de uma leitura intertextual que examina sua publicidade e uso de imagens (algu- 
mas reproduzidas no livro), passa por suas seções e protocolos de leitura, para chegar à análise do conteúdo de suas diversas matérias. Entre elas estão artigos de crítica literária, notas biográficas, discursos, necrológios, relatórios de viagem, resenhas de livros, notícias da Academia Brasileira de Letras, estudos de folclore, informações úteis, conselhos diversos etc.

Ao longo desse percurso, numa primeira parte do volume, a autora examina a bem-sucedida tradição da literatura de colportagem e situa a Livraria Garnier, que então publicava os mais famosos literatos do país e funcionava como um importante lugar de sociabilidade no Rio de Janeiro. A seguir, registra a regularidade do aspecto material do Almanaque e detecta a ampla rede de seus leitores, distribuída em vários estados da federação, mas predominantemente composta por setores médios urbanos. Tal rede - uma cartografia de circulação do Garnier - é percebida, por exemplo, pelos abundantes reclames e anúncios, como eram chamados, sendo também estimulada pelos agentes de venda de assinaturas.

Só então, na segunda e terceira partes, ela passa a examinar o que denomina de a sintaxe do Garnier, ou melhor, a tônica de seu projeto político-cultural que, não sendo homogêneo e comportando tensões, se constituía em uma plataforma de idéias e ideais republicanos. Algumas temáticas, como se demonstra, ganham grande espaço nas páginas da publicação, sendo articuladas pelos editores muito mais por uma lógica da estrutura intertextual, menos visível, do que pela organização de suas seções, muito mais evidente. Identificada esta estratégia de produção de sentido, o leitor é conduzido a alguns debates centrais do início do período republicano, sempre envolvendo a dupla face da política e da cultura, isto é, sempre remetendo a uma grande questão de fundo, que unia as duas dimensões: como tornar o Brasil uma nação moderna? Sem dúvida, atestam os editores, já se contava com a República, regime "mais evoluído", embora desvirtuado e, por isto, freqüentemente denunciado por sua marca bacharelesca, o que não impedia o reconhecimento de contribuições realizadas para o "melhoramento" do país. Apesar disto, pelos diagnósticos do periódico (e não só dele), no mais, "faltava quase tudo" ao Brasil. Faltava investimento no cultivo da língua portuguesa, distinta e mais rica que a de Portugal pelas contribuições de índios, negros e imigrantes, e instrumento fundamental para uma nação que se quisesse verdadeiramente una, política e culturalmente. Faltava um território que, por seu imenso 
tamanho e riquezas potenciais, precisava ser "conquistado", quer no sentido de ser assegurado, conhecido e representado - em cartas, mapas e dados estatísticos - quer no sentido de ser povoado e integrado, por meio de esforços de colonização e vias de comunicação, como o telégrafo e as estradas de ferro. Faltavam, enfim, políticas públicas que investissem na educação do povo, na modernização e na diversificação da agricultura e no incentivo aos novos conhecimentos científicos e técnicos, acreditados como capazes de trazer o progresso econômico e social.

Faltava, como a parte final do livro destaca, a produção de uma escrita da história, cujo "espírito" precisava ser autenticamente nacional, ou melhor, republicano, porque fundado na ação de um povo mestiço, finalmente reconhecido como sujeito ativo do tempo e do espaço brasileiros. Uma história que se entrelaçava com uma memória da nacionalidade, ambas expressão deste povo e desta pátria em formação. Com tal entendimento, acontecimentos e personagens do passado (colonial e imperial) e do presente (republicano) eram retomados e interpretados, tendo-se sempre como ótica um futuro difícil, porém alvissareiro.

A República é, assim, nas páginas do Garnier, tanto uma realidade do presente, como uma esperança de futuro. Ela traduz, sobretudo, uma promessa de progresso, identificado com a riqueza e a instrução do povo e do país. A República - palavra sugestivamente usada como sinônimo de Brasil e de pátria -, por ser nova e estar em movimento, necessitava urgentemente construir e organizar "seu" povo e "seu" território. Neste esforço, é evidente a posição atribuída e assumida pelos intelectuais do $\mathrm{Al}$ manaque, produtores de diagnósticos e de prognósticos críticos que buscavam conformar uma "opinião pública", instruir o povo e criar novas elites, mais esclarecidas e republicanas, política e eticamente. Um ambicioso projeto, que demandava tempo e competência, e tinha como idéia-força a produção de uma "cultura histórica republicana”, fundamento e sentido da comunidade política nacional. Um projeto civilizador, compartilhado por muitos intelectuais e políticos, brasileiros ou não, que deveria ser acionado "pelo alto", mas não necessariamente com o concurso direto do Estado. Neste sentido, a proposta do Garnier (de seus editores e colaboradores) era ampla e internacionalmente praticada, o que torna a leitura deste livro um exercício valioso para se pensar sobre intelectuais, cultura, política e nacionalismos na primeira metade do século XX. 